\title{
KEINDAHAN PENGGUNAAN USLUB AMR TERHADAP WANITA DALAM SURAH AL-BAQARAH
}

\author{
Syakirah Rifa'in@MOHD RIFAIN*1 \\ Mat Taib PA ${ }^{2}$ \\ Nurul Huda HAMZAH \\ 1, 2, ${ }^{3}$ Fakulti Bahasa dan Linguistik, Universiti Malaya, 50603 Kuala Lumpur \\ ${ }^{1}$ syakirah87@um.edu.my* \\ 2mattaib@um.edu.my \\ 3nurul.huda.hamzah@um.edu.my
}

Manuscript received 25 September 2020

Manuscript accepted 31 May 2021

*Corresponding author

https://doi.org/10.33736/ils.2601.2021

\begin{abstract}
ABSTRAK
Kajian ini membincangkan mengenai uslub amr terhadap wanita dalam dalam surah alBaqarah. Objektif kajian ini adalah untuk mengenal pasti bentuk dan tujuan amr bagi konteks iddah dan penyusuan dalam surah al-Baqarah serta rahsia tersirat penggunaan uslub amr terhadap wanita dalam surah al-Baqarah. Kajian ini merupakan kajian kualitatif yang menggunakan teknik analisis teks mengikut Kuckartz (2014) berdasarkan konteks ayat. Penulis menggunakan teori utama, iaitu Teori 'Abbas (1997) dan Teori Wahbah Al-Zuhayliy (1991). Dapatan kajian mendapati bahawa terdapat dua konteks yang melibatkan wanita dalam surah al-Baqarah, iaitu iddah dan penyusuan. Secara keseluruhannya, terdapat tiga ayat berkaitan wanita dalam surah al-Baqarah yang menggunakan satu bentuk amr sahaja iaitu uslub khabariy yang memberi makna insyaiy. Ketiga-tiga ayat $a m r$ tersebut mempunyai makna hakiki atau secara langsung iaitu wajib dan sunat. Secara kesimpulannya, bagi mesej tersirat penggunaan uslub amr kepada wanita iaitu uslub khabariy yang memberi makna insyaiy adalah bersifat kelembutan kerana ia melibatkan perkara-perkara yang sukar. Justeru, jelas menunjukkan bahawa ayat-ayat amr bagi konteks iddah dan penyusuan mempunyai makna hakiki dan bersifat kelembutan.
\end{abstract}

Kata Kunci: balaghah; uslub amr; wanita; al-Baqarah 


\begin{abstract}
This study discusses the language style of $a m r$ as revealed in surah al-Baqarah. The objective of this study is to identify the form and purpose of language style of amr for the context of iddah and breastfeeding in surah al-Baqarah, as well as the implicit meaning of the use of uslub amr towards women in surah al-Baqarah. This is a qualitative study that employs the text analysis technique by Kuckartz (2014) and the 'Abbas Theory (1997) and Wahbah Al-Zuhayliy Theory (1991). The findings revealed two contexts related to women, namely, iddah and breastfeeding. In total, there were three verses on women in surah al-Baqarah that used only one form of $a m r$ language style, which is uslub khabariy with the connotation of insyaiy. All three amr verses had a real meaning (hakiki) that connotes obligatory (wajib) and sunnah (sunat). In conclusion, the implicit message on the use of uslub amr to women is uslub khabariy which means insyaiy. It is gentle in nature as it involves complicated matters. Thus, it clearly shows that the verses of $a m r$ in the context of iddah and breastfeeding connote a real meaning (hakiki) and gentle in nature.
\end{abstract}

Keywords: Balaghah; the language style of amr; women; al-Baqarah

\title{
Pendahuluan
}

Al-Quran merupakan panduan hidup yang lengkap dan pedoman hidup manusia sepanjang zaman. Al-Quran juga merupakan mukjizat teragung Nabi Muhammad SAW dan kitab yang terpelihara sebagaimana firman Allah SWT dalam surah Fussilat;

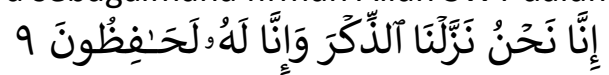

"Sesungguhnya Kamilah yang menurunkan al-Quran dan memeliharanya"

Al-Quran juga mengandungi pelbagai khazanah ilmu yang diperlukan oleh manusia untuk memakmurkan alam ini. Nabi Muhammad SAW sebagai utusan untuk menyampaikan Kitab ini kepada seluruh manusia dan model kepada kesempurnaan penghayatan al-Quran. Al-Quran mempunyai keindahan dan keaslian dari sudut balaghahnya yang tidak mungkin dapat ditandingi dan ditukar. Ungkapan balaghah yang digunakan sangat indah kerana mempunyai makna yang sempurna dan jelas serta terkesan di hati pembaca dan pendengar. Demikianlah juga ungkapan yang digunakan mampu menceritakan segalanya baik kegembiraan, kekaguman, ataupun ketakutan yang indah tersusun dan menarik perhatian (Syafrijal, 2013).

Bahasa Arab adalah antara bahasa yang tertua di dunia. Bahasa Arab telah diangkat darjat sebagai bahasa al-Quran oleh Allah SWT. Allah menyebutkan perkataan "Arab" dalam al-Quran antaranya dalam surah al-Zukhruf ayat 3:

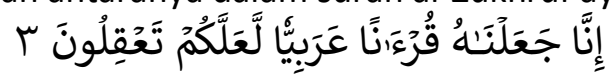

"Sesungguhnya kami jadikanKitab itu sebagai al-Quran yang diturunkan dengan bahasa Arab supaya kamu (menggunakan akal) memahaminya" 
Disebut juga dalam surah Fussilat ayat 3:

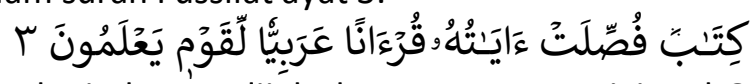

"Sebuah Kitab yang dijelaskan ayat-ayatnya iaitu al-Quran yang diturunkan dalam bahasa Arab bagi faedah orang-orang yang mengambil tahu dan memahami kandungannya"

Bahasa Arab sangat istimewa kerana merupakan bahasa al-Quran. Bahasa Arab kekal sehingga ke hari ini disebabkan al-Quran yang menjadi sumber rujukan utama dan panduan seluruh umat Islam. Al-Quran juga telah menjadikan bahasa Arab kaya dengan kosa kata dan keindahan gaya bahasanya tidak dapat ditandingi oleh manusia (Azhar, 2008).

Rahsia kemukjizatan al-Quran dalam ilmu Balaghah jelas dapat dilihat berdasarkan kajian gaya bahasanya dengan penyampaian makna yang berbeza. Balaghah merupakan suatu disiplin ilmu yang berlandaskan kepada penghayatan keindahan uslub serta penjelasan perbezaan yang samar antara pelbagai uslub (Abdullah, 2017).

Uslub merupakan bentuk penyampaian yang digunakan oleh penutur bagi menyampaikan hasrat atau maksud yang terpendam di dalam dirinya dengan gaya bahasa tersendiri. Uslub yang digunakan oleh seseorang berbeza antara satu dengan yang lain berdasarkan kepada kekuatan peribadi, pengalaman, persekitaran dan lainlain. Oleh kerana itulah setiap penyampaian memerlukan uslub yang tertentu (Abdul Wahid, 2006). Menurut Lisan Arab, dari sudut bahasa perkataan أَمَرَ يَاْْدُر أَْْرً bermaksud perintah atau suruhan (Ibn Manzur, t.t.). Justeru, secara kesimpulannya uslub amr bermaksud gaya bahasa perintah yang digunakan dalam al-Quran sebagaimana fokus kajian ini. Uslub amr digunakan dalam al-Quran khususnya surah al-Baqarah berdasarkan ayat-ayat yang ditujukan kepada wanita iaitu bagi konteks iddah dan penyusuan.

Uslub atau gaya bahasa sangat penting untuk dikaji sebagaimana dijelaskan oleh Mhd Ramli et al. (2015) bahawa penelitian khusus perlu dilakukan untuk mengkaji aspek keindahan bahasa yang luar biasa serta kata dan maknanya yang saling mempunyai kaitan sehingga melahirkan ungkapan-ungkapan yang memukau hati dan perasaan pembaca. Melalui gaya bahasa ini dapat mengajak pembaca menghayati dan mendalami kandungan yang ingin disampaikan.

Penulis memfokuskan kepada konteks wanita dalam kajian ini kerana terdapat banyak kelebihan dan keistimewaan wanita yang disebut dalam al-Quran antaranya surah al-Nisa' khusus untuk wanita. Menurut Fatin Nazmin et al. (2018) yang mengkaji mengenai surah al-Nisa' menjelaskan bahawa al-Quran telah mengangkat darjat dan penghormatan terhadap wanita sejak 1400 tahun lalu sebagaimana dalam surah al-Nisa' yang mengangkat darjat wanita yang tertindas sejak sekian lama. Turunnya al-Quran membela wanita menerusi surah al-Nisa' adalah satu penghormatan tertinggi dalam Islam. 
Di samping itu juga, tedapat ayat yang Allah SWT memuji wanita solehah sebagaimana dalam surah al-Tahrim ayat 11 ,

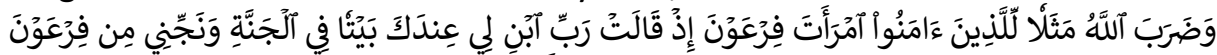

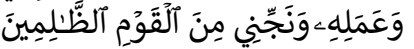

"Dan Allah mengemukakan satu misal perbandingan yang menyatakan tidak ada mudaratnya) kepada orang mukmin (berhubung rapat dengan orang kafir kalau tidak terjejas keadaan imannya, iaitu: Perihal isteri Fir'aun ketika dia berkata: wahai Tuhanku, binalah untukku sebuah rumah di sisiMu dalam syurga dan selamatkanlah daku dari

Fir'aun dan perbuatannya serta selamatkanlah daku dari kaum yang zalim."

Walau bagaimanapun, kajian yang disebutkan di atas hanya menjelaskan berkaitan penghormatan wanita dalam al-Quran. Justeru, dalam kajian ini penulis ingin merungkaikan adakah keistimewaan dan penghormatan terhadap wanita khususnya digunakan dalam ayat yang bersifat amr atau perintah dalam surah al-Baqarah.

Surah al-Baqarah dipilih kerana surah ini menjelaskan uslub amr terhadap wanita terutama berkaitan penyusuan dan iddah yang menjadi fokus utama kepada kajian ini. Bagi konteks iddah telah disebut dua kali dalam surah al-Baqarah, begitu juga bagi konteks perintah supaya menyusukan anak ditujukan buat wanita hanya terdapat dalam surah al-Baqarah. Selain itu juga, penulis telah memilih surah al-Baqarah kerana di dalamnya mengandungi banyak ayat $a m r$ yang mana sebahagian besar tajuk-tajuk dan hukum hakam perundangan Islam terkandung dalamnya. Sebagaimana terdapat dalam tafsir Ibn Kathir (1999) yang menyatakan bahawa sebahagian ulama' menjelaskan surah al-Baqarah mengandungi seribu khabar berita, seribu perintah dan seribu larangan.

\section{Kajian Literatur}

\section{Definisi Amr}

Manakala menurut Yahya dan Fatchur (1986), amr ialah suatu lafaz yang digunakan oleh orang yang lebih tinggi kedudukannya untuk menuntut kepada orang yang lebih rendah kedudukannya agar melakukan sesuatu perbuatan. Antara contoh amr ialah sebagaimana firman Allah SWT dalam surah al-Baqarah ayat 110:

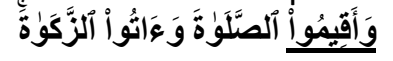

"Dan dirikanlah solat serta tunaikanlah zakat"

Secara umumnya, amr mempunyai maksud hakiki iaitu secara langsung dan majazi iaitu tidak langsung. Wahbah Al-Zuhayliy (1991) menjelaskan bahawa gaya hakiki menggunakan perkataan dengan makna sebenar manakala gaya majazi menggunakan satu perkataan dengan makna lain yang bukan asal kerana ada hubungan dengan makna asal tersebut. Allah SWT berfirman: 
Contohnya firman Allah SWT dalam surah al-Baqarah ayat 228 iaitu,

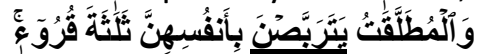

"Wanita-wanita yang ditalaq (hendaklah) menahan diri (menunggu) sehingga tiga

kali suci".

Ayat tersebut adalah ayat penyata yang menyatakan bahawa wanita yang ditalak itu menunggu sampai tiga kali suci. Akan tetapi ayat tersebut memberi maksud suruhan, iaitu wanita-wanita yang ditalak hendaklah menunggu iddahnya sehingga tiga kali suci. Seterusnya bagi makna majazi atau makna tersirat dalam konteks tertentu kalimah amr terkadang menyimpang dari makna asalnya sebaliknya menunjukkan makna-makna lain, antaranya ialah makna ibahat (harus), tahdid (ancaman) irsyad (bimbingan), al-qudrah (kekuasaan), takhyir (pilihan) dan sebagainya.

Allah SWT berfirman dalam surah al-Baqarah:

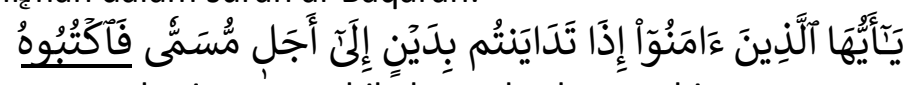

"Hai orang-orang yang beriman, apabila kamu berhutang hingga masa yang ditetapkan, hendaklah kamu menulisnya." (Al-Baqarah: 282)

Berdasarkan ayat فاكتبوه menunjukkan perintah supaya mencatat apabila berhutang. Dari segi makna tersiratnya ia menunjukkan makna irsyad atau sebagai petunjuk ketika bermuamalah menguruskan masalah hutang dan harta kekayaan. Dalam ayat tersebut, Allah SWT mendidik manusia dengan memberi petunjuk supaya mencatat hutang kerana cara tersebut lebih dipercayai dan dapat menghindarkan perbalahan. Tetapi melakukan yang demikian itu tidak sampai wajib hukumnya, kerana dengan tidak menulis pun tercapai juga maksud tersebut. Justeru, petunjuk tersebut adalah arahan daripada Allah SWT untuk kemaslahatan dunia. Ia merupakan makna majazi atau makna tersirat yang mana bukanlah perintah wajib walaupun menggunakan fi'l amr. Begitu juga firman Allah SWT dalam surah ad-Dukhan:

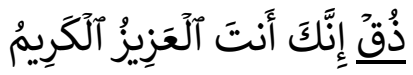

"Rasalah sesungguhnya kamu manusia yang mulia." (Al-Dukhan: 49)

Amr dalam ayat ini pada ungkapan ذق (rasalah) bukanlah memberi makna wajib tetapi merupakan bahasa sindiran daripada majazi iaitu al-ihanah bertujuan untuk menghina dan menjatuhkan air muka yang ditujukan kepada orang-orang kafir yang masuk neraka sebagai penghinaan terhadap mereka. Dalam ayat ini Allah SWT berkata kepada orang kafir yang masuk neraka dan di sini sebagai ejekan terhadap orang kafir tersebut sesuai dengan balasan di atas perbuatan mereka. 


\section{Bentuk-bentuk Amr}

Amr mempunyai empat bentuk, iaitu:

1. Fi'l amr iaitu kata kerja perintah atau kata kerja imperatif yang menuntut untuk dilaksanakan selepas ia diperintahkan. Contohnya firman Allah SWT:

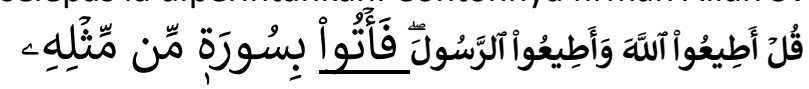

"Maka datangkanlah satu surah yang sebanding dengan Al-Quran itu." (Al-Baqarah: 23)

2. Lam amr yang bersambung dengan fi'l mudari'yang bermaksud hendaklah. Contohnya dalam surah al-Talaq ayat 7:

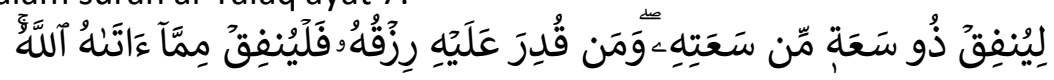

"Hendaklah orang yang mampu memberi nafkah menurut kemampuannya, dan sesiapa yang disempitkan rezekinya maka hendaklah ia memberi nafkah dari apa yang Allah berikan padanya."

3. Ism fi'l seperti firman Allah SWT:

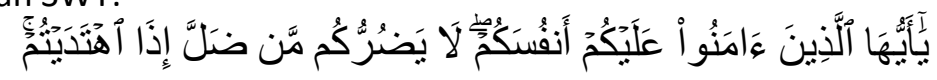

"Wahai orang-orang yang beriman, jagalah diri kamu, tiadalah orang yang sesat itu akan memberi mudarat kepada kamu apabila kamu telah mendapat hidayah petunjuk." (Al-

Maidah: 105)

4. Uslub khabariy yang memberi makna insyaiy. Firman Allah SWT:

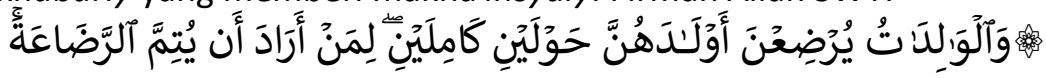

"Para ibu hendaklah menyusukan anak-anaknya selama dua tahun penuh, yaitu bagi yang ingin menyempurnakan penyusuan." (Al-Baqarah: 228)

Seterusnya, terdapat juga bentuk uslub khabariy yang lain, antaranya ialah (Yahya \& Fatchur, 1986):

a) Menggunakan ungkapan atau perkataan yang menggunakan perkataan amara sebagaimana firman-Nya:

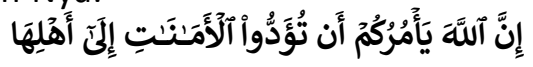

"Sesungguhnya Allah menyuruh kamu menunaikan amanat kepada yang berhak menerimanya." (Al-Nisa': 58)

b) Menggunakan ungkapan perkataan yang menggunakan perkataan farada sebagaimana firman-Nya:

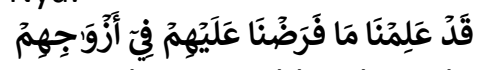

"Kami telah mengetahui apa yang kami wajibkan kepada mereka perihal isteri-isteri mereka." (Al-Ahzab: 50) 
c) Menggunakan ungkapan perkataan yang menggunakan perkataan berakar kata kataba sebagaimana firman-Nya:

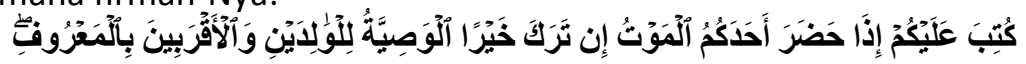

"Diwajibkan atas kamu apabila di antara kamu kedatangan maut, jika ia meninggalkan harta yang banyak, berwasiat untuk ibu bapa dan kerabat-kerabatnya." (Al-Baqarah:

180)

d) Memberitakan suatu perbuatan yang harus dilakukan oleh manusia bahawa perbuatan itu untuknya sebagaimana firman-Nya:

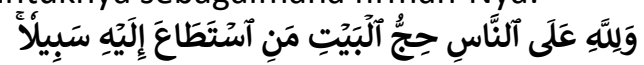

“Mengerjakan haji adalah kewajipan manusia terhadap Allah." (Ali-Imran: 97)

e) Menyatakan bahawa perbuatan itu adalah baik atau merupakan perbuatan bakti. Sebagaimana firman-Nya:

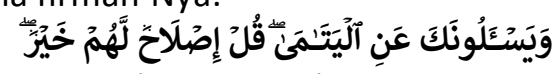

"Katakanlah: Mengurus mereka (anak yatim) secara patut adalah baik." (Al-Baqarah: 220)

f) Menjanjikan dengan suatu sifat yang baik. Contohnya firman Allah SWT:

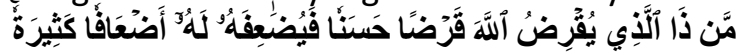

"Siapakah yang mahu memberi pinjaman kepada Allah pinjaman yang baik

(menafkahkah hartanya ke jalan Allah) maka Allah akan melipatgandakan rezekinya."

(Al-Baqarah: 245)

\section{Tujuan Lafaz Amr}

Pada asalnya $a m r$ itu adalah untuk mewajibkan iaitu merujuk kepada tuntutan atau perintah supaya melakukan sesuatu perbuatan daripada pihak yang lebih tinggi kepada pihak yang lebih rendah (Abdul Wahid Salleh, 2006). Namun begitu, para fuqaha' berbeza pendapat mengenai hakikat maksud amr (Al-Rifa'I \& Rafi' Taha 2007):

1) Secara hakikatnya amr menunjukkan wajib dan tidak mempunyai maksud lain melainkan ada qarinah.

2) Secara hakikatnya amr menunjukkan sunat.

3) Secara hakikatnya amr menunjukkan al-ibahat atau harus.

4) Secara hakikatnya amr menunjukkan makna kehendak.

5) Secara hakikatnya amr yang dikeluarkan oleh Allah SWT menunjukkan wajib manakala daripada Rasulullah SAW adalah sunat.

6) Hakikatnya amr adalah musytarak antara wajib dan sunat.

7) Amr adalah musytarak antara wajib, sunat dan al-ibahat.

8) Amr adalah musytarak antara wajib, sunat, al-ibahat, al-karahat (makruh) dan al-tahrim (haram).

9) Amr adalah musytarak antara wajib, sunat, al-ibahat, al-irsyad, dan al-tahdid. 
Pendapat lain pula menjelaskan bahawa amr adalah musytarak antara wajib, sunat, al-tahdid, al-ta'jiz, al-ibahat dan al-takwin.

Perlu dinyatakan bahawa bagi makna balaghi 'Abbas (1997) menjelaskan bahawa ia tidak hanya terhad kepada tujuan-tujuan tersebut sahaja bahkan mungkin terdapat makna amr yang lain yang difahami dari konteks ayat seperti talhif (keluhan), takzib (pendustaan), taslim (penyerahan) dan sebagainya.

Persoalan yang timbul ialah apakah makna-makna $a m r$ yang terdapat dalam konteks yang digunakan terhadap wanita dalam surah al-Baqarah? Adakah semua ayat amr mempunyai makna hakiki dan majazi? Kajian ini akan merungkaikan adakah konteks yang digunakan terhadap wanita mempunyai makna hakiki atau majazi? Inilah persoalan pertama yang akan cuba dijawab dalam kajian ini. Seterusnya persoalan kedua terdapat pelbagai jenis bentuk amr dalam surah al-Baqarah, namun adakah Allah menggunakan bentuk yang khusus atau bentuk yang sama untuk wanita? Sekiranya Allah menggunakan bentuk yang khusus untuk wanita, adakah bentuk tersebut mempunyai maksud yang tersirat? Justeru, dalam kajian ini penulis hanya memfokuskan kepada ayat amr yang ditujukan kepada wanita dalam surah al-Baqarah.

\section{Metodologi Kajian}

Kajian ini akan menganalisis dan menghuraikan secara terperinci ayat-ayat $a m r$ dengan menggunakan kaedah analisis teks dalam surah al-Baqarah dari sudut tujuan amr. Sehubungan dengan itu, dalam kajian ini penulis menggunakan penyelidikan kualitatif.

Kajian ini menggunakan metod analisis teks. Justeru, dalam kajian ini penulis menggunakan teks al-Quran yang memfokuskan kepada struktur ayat $a m r$ dalam surah al-Baqarah. Secara umumnya proses analisis teks mengikut Kuckartz (2014) berdasarkan kajian ini terdiri daripada lima kategori iaitu membaca dan menafsirkan teks, membina kategori bentuk-bentuk $a m r$, menentukan konteks ayat, menganalisis ayat-ayat $a m r$ dan mempersembahkan dapatan kajian. Secara ringkasnya, penulis ringkaskan kategori analisis teks dalam Rajah 1.

Tiga ayat yang dipilih dalam kajian ini kerana hanya tiga ayat tersebut terdapat dalam surah al-Baqarah yang ditujukan khusus untuk wanita. Proses analisis teks mengikut Kuckartz (2014) dipilih kerana ia sesuai dengan kajian ini yang terdiri daripada lima kategori iaitu kategori pertama penulis membaca dan menafsirkan teks (al-Quran) berdasarkan tafsir-tafsir lama dan moden antaranya Wahbah al-Zuhayliy, Ibn 'Asyur, alMaraghiy dan sebagainya. Seterusnya penulis membina kategori bentuk amr sama ada ia terdiri dari fi'l amr, ism fi'l amr atau uslub khabariy yang memberi makna insya'iy, kemudian menentukan konteks ayat sama ada ayat tersebut ditujukan untuk wanita atau sebaliknya. Setelah dikenal pasti ayat tersebut, penulis menganalisis ayat-ayat $a m r$ dan mempersembahkan dapatan kajian. 


\section{Rajah 1}

Analisis Teks Kuckartz (2014)

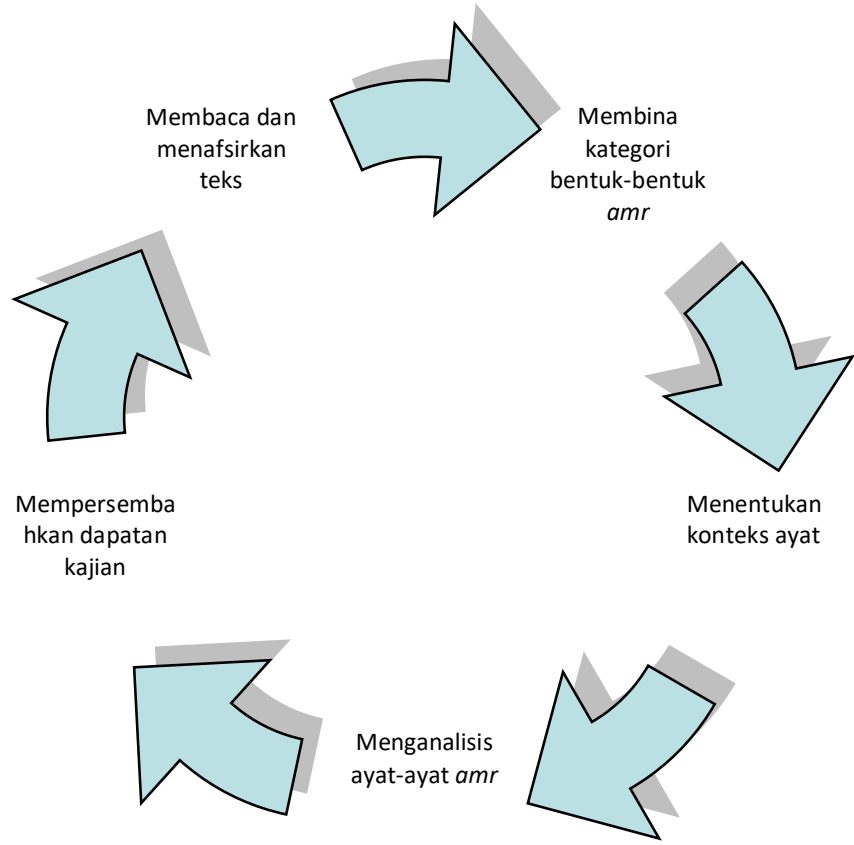

Dalam kajian ini penulis menggunakan Teori 'Abbas (1997) dan Teori Wahbah Al-Zuhayliy (1991). Hal ini kerana teori tersebut mengandungi dua bahagian utama iaitu turuq amr dan al-ma'ani al-majaziyyat. Dalam turuq amr terdapat lima jenis bentuk, iaitu fi'l amr, lam amr, masdar, ism fi'l, dan uslub khabariy. Manakala bagi al-ma'ani almajaziyyat terdapat 20 jenis tujuan antaranya al-ibahat, al-tamanni, al-qudrah dan lainlain lagi. Penulis menggunakan teori ini kerana ia lengkap dan bersesuaian dengan kehendak kajian serta menepati objektif kajian di samping ia merangkumi aspek balaghah secara khusus. Justeru, teori tersebut digunakan untuk menganalisis dan merumuskan ayat-ayat $a m r$ berdasarkan konteks ayat. Bagi objektif pertama, ia selari dengan Teori 'Abbas iaitu turuq amr terdapat lima jenis bentuk antaranya uslub يتربصن khabariy sebagaimana dalam ayat 233 yang menjelaskan bahawa pada ungkapan bagi konteks iddah yang menyuruh supaya wanita yang kematian suami menunggu sehingga tamat tempoh iddah sebagai bentuk uslub khabariy yang memberi makna insya'iy, manakala bagi tujuan amr pula ia bermaksud wajib sesuai dengan al-ma'ani almajaziyyat.

Bagi mesej tersirat penggunaan bentuk amr penulis menggunakan Teori Wahbah Al-Zuhayliy (1991) kerana ia bersesuaian dan menepati ciri objektif kajian ini. la selari dengan Teori Wahbah Al-Zuhayliy (1991) yang menjelaskan bahawa bentuk uslub khabariy yang memberi makna insya'iy bermaksud kelembutan. Hal ini dapat dilihat pada ungkapan يتربصن dalam ayat 233 adalah merupakan bentuk uslub khabariy yang memberi makna insya'iy bersifat kelembutan. 
Penulis menganalisis dan mentarjihkan tujuan amr berdasarkan tafsir yang menjelaskan mengenai pendapat ayat tersebut untuk menentukan tujuan amr. Sebagai contoh bentuk amr dalam ayat 233 adalah uslub khabariy yang memberi makna insyaiy pada ungkapan يرضعن. Menurut Tantawiy (1987), dalam ayat ini terdapat dua pendapat tujuan amr bagi ungkapan يرضعن yang bermaksud hendaklah menyusukan anak-anak iaitu sunat dan wajib. Justeru, pendapat akan ditarjihkan (diberatkan) salah satu dari keduanya untuk beramal dengan dalil yang lebih kuat. Memandangkan jumhur fuqaha' pula berpendapat tujuan amr tersebut sunat iaitu tidak diwajibkan atas ibu menyusukan anaknya melainkan jika telah ditetapkan ketika bayi oleh ibu yang menyusukan anaknya dan anak tersebut enggan menyusu dengan orang lain atau seorang bapa tidak mampu mengupah ibu susu untuk menyusu ataupun berkemampuan tetapi tidak ada ibu susu untuk anaknya. la disunatkan kerana secara umumnya susu ibu adalah susu terbaik dan belas ihsan ibu lebih banyak serta tidak dapat menandingi orang lain (Al-Sabuniy, 1980). Secara kesimpulannya, penulis bersetuju dengan pendapat yang menyatakan amr tersebut menunjukkan sunat menyusukan anak selama dua tahun penuh kerana ia merupakan tanggungjawab seorang ibu. Hal ini kerana susu ibu adalah susu terbaik untuk anak-anaknya.

Pentarjihan penting dalam ulasan sekiranya terdapat dua pendapat kerana hanya satu hukum yang diguna pakai terutama apabila ia melibatkan hukum hakam fiqh. Namun begitu, tidak semua ayat yang dianalisis memerlukan kepada pentarjihan sebagaimana konteks iddah yang mempunyai satu pendapat sahaja iaitu diwajibkan menunggu sebelum berkahwin lain selama tiga kali suci bagi wanita yang diceraikan suami.

\section{Hasil dan Perbincangan}

\section{Ayat 228: Iddah}

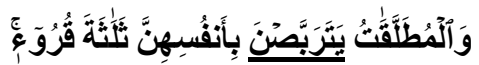

"Isteri-isteri yang diceraikan itu hendaklah menunggu dengan menahan diri mereka (dari berkahwin) selama tiga kali suci (daripada haid)"

Ayat tersebut memerintahkan kepada wanita yang diceraikan suaminya supaya menahan diri mereka sehingga tamat tempoh iddah sebelum berkahwin lain selama tiga kali suci (Al-Durrah, 2008). Iddah ialah satu tempoh masa menunggu yang wajib dilakukan oleh isteri dan dilarang berkahwin selepas kematian atau bercerai dengan suaminya. Iddah disyariatkan atas beberapa tujuan antaranya untuk memastikan bersihnya rahim iaitu tidak bercampur keturunan dengan keturunan lain, memberi peluang supaya keduanya kembali semula memperbaiki kesilapan dalam kehidupan rumah tangga setelah berpisah, menjaga nama baik isteri, memelihara nikmat dan menghargai perkahwinan, memikirkan kesan-kesan perceraian dan urusan kehidupan selepas perceraian dan untuk keharmonian keluarga serta merancang masa depan anakanak dengan lebih baik (Wahbah Al-Zuhayliy, 1991). 
Amr pada ungkapan يتربصن berbentuk uslub khabariy yang memberi makna insyaiy. Menurut Al-Qurtubiy ada pendapat yang menyatakan bahawa ungkapan tersebut merupakan amr iaitu ليتربص yang bermaksud hendaklah menunggu tetapi lam telah dibuang (Al-Qurtubiy, 2006). Diperhatikan juga, tafsir Al-Wasit menjelaskan pendapat yang sama sebagaimana al-Qurtubiy (Tantawiy, 1987). Hal ini berbeza dengan pendapat lain antaranya Al-Raziy (1981) yang menyatakan bahawa tidak diragui lagi ungkapan amr يتريص ialah uslub khabariy yang memberi makna insyaiy (Al-Raziy, 1981). Menurut Wahbah Al-Zuhayliy (1991), tujuan amr pada ungkapan يتريصن yang bermaksud hendaklah menunggu dalam ayat tersebut menunjukkan wajib. Al-Maraghiy (1946) pula menjelaskan wanita yang berada dalam keadaan iddah diwajibkan menahan diri dan nafsunya untuk berkahwin lain sehingga sempurna tempoh yang ditetapkan meskipun keinginan tersebut wajar bagi wanita.

Bentuk amr yang digunakan dalam ayat 228 ialah uslub khabariy yang bermaksud insya'iy pada ungkapan يتربصن yang menyuruh supaya wanita yang diceraikan menunggu sehingga tamat tempoh iddah. Wahbah Al-Zuhayliy (1991) berpendapat bahawa bentuk uslub khabariy yang memberi makna insya'iy bersifat kelembutan. Hal ini sangat bersesuaian dengan keadaan kaum wanita yang dalam keadaan iddah kerana iddah merupakan masa kesedihan seorang wanita yang diceraikan oleh suami.

\section{Ayat 234: Iddah}

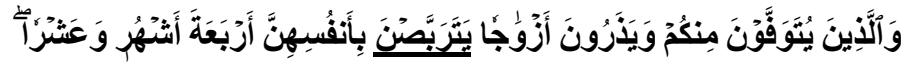

"Orang yang meninggal dunia antara kamu, sedangkan mereka meninggalkan isteriisteri, hendaklah menunggu (beridah) selama empat bulan sepuluh hari."

Ayat ini menjelaskan perintah iddah kematian suami yang mana Allah SWT memerintahkan supaya wanita yang diceraikan menunggu sehingga tempoh empat bulan sepuluh hari iaitu tidak terdedah kepada umum, tidak berhias dan berwangiwangian serta tidak keluar daripada rumah selama dalam tempoh iddah (Al-Sabuniy, 1980). Dalam arahan ini yang ditujukan kepada perempuan, digunakan bentuk uslub khabariy yang memberi makna insya'iy pada ungkapan يتربصن bagi konteks iddah yang menyuruh supaya wanita yang kematian suami menunggu sehingga tamat tempoh iddah. Sebagaimana yang dijelaskan sebelum ini bentuk amr ini bersifat kelembutan. Hal ini sangat bersesuaian dengan keadaan kaum wanita yang dalam keadaan iddah kerana iddah merupakan masa kesedihan seorang wanita setelah kehilangan suami. Wahbah Al-Zuhayliy (1991) turut menjelaskan bahawa ungkapan ini digunakan dengan lembut kerana padanya terdapat penghormatan yang bersesuaian dengan keadaan wanita berada dalam keadaan yang sukar. Oleh kerana itulah ia tidak diperintahkan dengan ungkapan yang terang. 


\section{Ayat 233: Penyusuan}

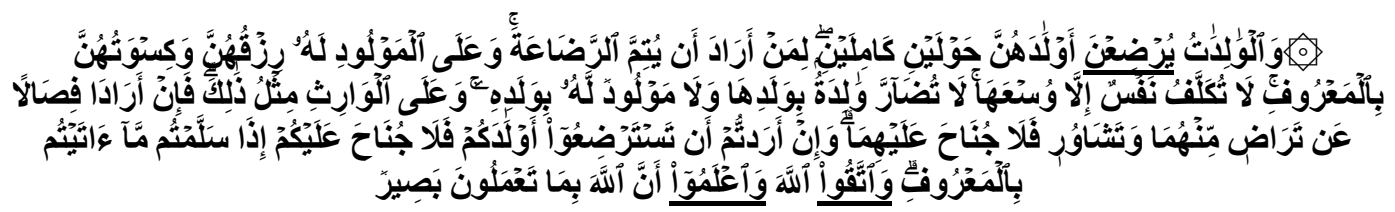

"Ibu-ibu hendaklah menyusukan anak-anak mereka selama dua tahun genap iaitu bagi orang yang hendak menyempurnakan penyusuan itu. Kewajipan bapa pula adalah memberi rezeki (memberi makan) dan pakaian kepada ibu itu mengikut cara yang sepatutnya. Tidaklah dibebankan seseorang melainkan kemampuannya. Janganlah jadikan seseorang ibu itu menderita kerana anaknya dan jangan juga menjadikan seseorang bapa itu menderita kerana anaknya dan waris juga menanggung kewajipan yang tersebut (jika si bapa tiada). Kemudian jika kedua-duanya (suami isteri) bersepakat mahu menghentikan penyusuan itu sesudah berunding, maka tidaklah menjadi kesalahan. Jika kamu hendak beri anak-anak kamu menyusu kepada orang lain, maka tidak ada salahnya bagi kamu apabila kamu serahkan (upah) yang kamu mahu beri itu dengan cara yang betul. Bertakwalah kamu kepada Allah serta ketahuilah sesungguhnya Allah Maha Melihat apa yang kamu lakukan."

Ayat tersebut merupakan perintah Allah SWT supaya menyusui anak-anak mereka dengan penyusuan yang sempurna selama dua tahun penuh. Dalam ayat sebelum ini Allah SWT telah menyebutkan hukum hakam nikah dan talak, disebutkan juga kesan-kesan perkahwinan kerana pasangan yang bercerai mungkin mempunyai anak yang sedang menyusu. Boleh jadi anak tersebut terabai kerana kebencian suami dan isteri. Kerana itulah Allah SWT memerintahkan para ibu supaya menyempurnakan hak anak-anak. Allah SWT telah menetapkan tempoh bagi penyusuan selama dua tahun jika kedua-duanya bersetuju (Wahbah Al-Zuhayliy, 1991).

Bentuk amr dalam ayat tersebut iaitu uslub khabariy yang memberi makna insyaiy pada ungkapan يرضعن. Menurut Tantawiy (1987) tujuan amr bagi ungkapan يرضعن yang bermaksud hendaklah menyusukan anak-anak mempunyai dua keadaan iaitu sunat dan wajib. la menjadi sunat dengan tiga keadaan, iaitu bapa mampu mengupah ibu susuan bagi anaknya, kehadiran ibu susu selain ibu kandungnya dan anak tersebut mahu menyusu dengan orang lain. Manakala ia menjadi wajib ke atas ibu selagi ia tidak bercerai atau sekiranya anak tersebut tidak mahu menyusu dengan orang lain ataupun sekiranya tidak ada bapa. Namun, beliau mengecualikan wanita yang berkedudukan dan tidak diwajibkan ke atasnya (Al-Sabuniy, 1980; Tantawiy, 1987). Jumhur fuqaha' pula berpendapat tujuan amr tersebut sunat iaitu tidak diwajibkan atas ibu menyusukan anaknya melainkan jika telah ditetapkan ketika bayi oleh ibu yang menyusukan anaknya dan anak tersebut enggan menyusu dengan orang lain atau seorang bapa tidak mampu mengupah ibu susu untuk menyusu ataupun berkemampuan tetapi tidak ada ibu susu untuk anaknya. la disunatkan kerana secara umumnya susu ibu adalah susu terbaik dan belas ihsan ibu lebih banyak serta tidak 
dapat menandingi orang lain (Al-Sabuniy, 1980). Secara kesimpulannya, penulis bersetuju dengan pendapat yang menyatakan amr tersebut menunjukkan sunat menyusukan anak selama dua tahun penuh kerana ia merupakan tanggungjawab seorang ibu. Hal ini kerana susu ibu adalah susu terbaik untuk anak-anaknya.

Ungkapan برضعن bagi konteks penyusuan menggunakan amr berbentuk uslub khabariy yang memberi makna insya'iy. Justeru, ia adalah bersifat kelembutan sebagaimana pendapat Wahbah Al-Zuhayliy (1991). Ciri amr yang bersifat kelembutan ini dapat diaplikasi kepada ayat ini kerana isteri berada dalam keadaan yang sukar dan hal ini bertepatan dengan pendapat Wahbah Al-Zuhayliy (1991) yang menyatakan bahawa konteks asal ayat tersebut ditujukan kepada isteri yang telah diceraikan. Bahkan juga, ayat ini didatangkan selepas ayat-ayat talaq. Di samping itu juga, hal ini jelas kerana isteri yang melahirkan anak akan berada dalam keadaan tertekan sebagaimana digambarkan dalam surah al-Ahqaf ayat 15 yang bermaksud, "Ibunya telah mengandungkannya dan melahirkan dengan menanggung susah payah". Begitu juga kesusahan seorang ibu yang menyusukan anak digambarkan dalam surah Luqman ayat 14 yang bermaksud, "Ibunya telah mengandungkannya dalam keadaan lemah yang bertambah-tambah dan tempoh menceraikan susunya ialah dalam tempoh dua tahun". Justeru, jelas menunjukkan bahawa kelembutan yang digunakan dalam ungkapan tersebut sangat bersesuaian dengan situasi mereka yang berada dalam keadaan sukar dan tertekan.

Seterusnya ungkapan ficl amr pada ungkapan اعلموا dan اتقو merupakan suruhan supaya bertakwa dan amaran terhadap seksaan Allah SWT ditujukan kepada mukhatab atau pihak kedua iaitu orang yang terlibat secara langsung dalam kewajipan menunaikan tanggungjawabnya iaitu para suami. Bentuk ini adalah untuk menjelaskan perkara asas yang utama iaitu takwa. Ketakwaan merupakan perkara yang utama dalam semua perkara sehinggakan diberi perintah yang berbentuk ancaman sekiranya manusia ingkar dan tidak takut kepada-Nya. Justeru, dalam konteks ini walaupun isteri diharuskan menyusukan anak-anak mereka, namun para suami diwajibkan menjalankan tanggungjawab mereka dengan baik dan takut kepada Allah SWT. Wahbah Al-Zuhayliy (1991) menjelaskan bahawa para suami mestilah menjaga daripada berlakunya kecuaian daripada hukum tersebut kerana Allah SWT Maha Mengetahui dan akan membalas segala amalan manusia. Sekiranya para suami menunaikan segala hak isteri dan anakanak mereka dan menjauhkan kemudaratan daripada mereka maka anak-anak akan menjadi contoh generasi yang soleh di dunia dan mendapat ganjaran di akhirat. Manakala sekiranya mengikut hawa nafsu, anak-anak akan menjadi simbol kejahatan dan fitnah di dunia serta akan mendapat azab di akhirat. Berdasarkan penjelasan tersebut menunjukkan bahawa ayat amr pada ungkapan اتقو اعلمو I ditujukan kepada para suami maka penulis tidak akan memfokuskan kepada perkataan tersebut.

Sementara uslub khabariy yang memberi makna insya'iy bersifat kelembutan sesuai dengan perintah terhadap perempuan. Ayat yang bersifat kelembutan iaitu uslub khabariy yang memberi makna insya'iy ditujukan kepada kaum wanita. Hal ini selari 
dengan fitrah kerana kaum lelaki dicipta sebagai pemimpin dan pelindung kepada kaum wanita dan mereka dituntut supaya berbuat baik kepada kaum wanita. Hal ini juga bersesuaian dengan perkataan perempuan iaitu al-untha dalam bahasa Arab sebagaimana dijelaskan oleh Ma'luf (1957) dalam mu'jam al-Munjid ia memberi maksud lembut dan tidak keras.

Keistimewaan wanita atau ibu tidak dapat disangkal lagi sebagaimana disebut juga dalam sebuah hadis Rasulullah SAW yang mengangkat martabat ibu dari bapa. Ini kerana melihat kepada pengorbanan ibu yang hebat yang melahirkan dan mengasuh seseorang anak dengan penuh kasih dan sayang. Hadis ini menyebutkan bahawa ibu berada lebih tiga tingkat daripada ayah:

"Seorang lelaki datang kepada Rasulullah SAW lalu berkata, "Wahai Rasulullah, siapakah orang yang paling berhak untuk aku hormati?"Baginda menjawab, "Ibumu!" Lelaki itu terus bertanya, "Kemudian siapa?" Rasulullah SAW menjawab, "Ibumu!" Lelaki itu bertanya lagi, "Kemudian siapa?" Rasulullah SAW menjawab, "Ibumu!" Sekali lagi lelaki itu bertanya, "Kemudian siapa?" Rasulullah SAW menjawab, "Bapamu!" (Al-Bukhariy, 2002)

Dalam Hadith yang lain pula Rasulullah SAW bersabda: "Barang siapa yang menanggung dua anak perempuan, lalu berbuat baik kepada mereka, maka mereka akan menjadi tirai pencegah baginya dari api neraka" (Al-Bukhariy, 2002). Dalam al-Quran juga Allah mengangkat martabat wanita dengan memuliakan wanita sebagai ibu. Ini dijelaskan dalam surah al-Ahqaf ayat 46:

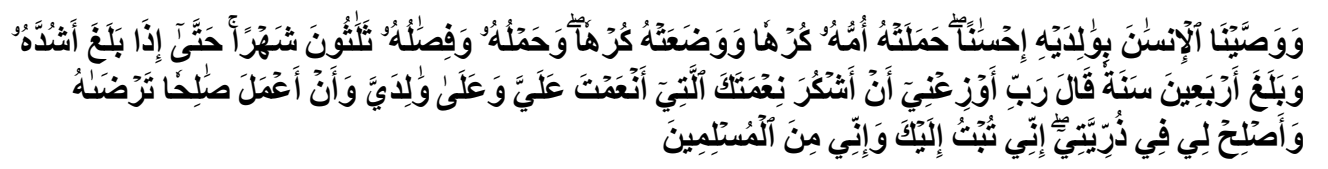

"Dan Kami wajibkan manusia berbuat baik kepada kedua ibu bapanya; ibunya telah mengandungnya dengan menanggung susah payah dan telah melahirkannya dengan menanggung susah payah. Sedang tempoh mengandungnya beserta dengan tempoh menceraikan susunya ialah dalam masa tiga puluh bulan. Setelah ia besar sampai ke peringkat dewasa yang sempurna kekuatannya dan sampai ke peringkat umur empat puluh tahun, berdoalah ia dengan berkata: "Wahai Tuhanku, ilhamkanlah daku supaya tetap bersyukur akan nikmatmu yang engkau kurniakan kepadaku dan kepada ibu bapaku, dan supaya aku tetap mengerjakan amal soleh yang Engkau redai; dan jadikanlah sifat-sifat kebaikan meresap masuk ke dalam jiwa zuriat keturunanku. Sesungguhnya aku bertaubat kepadamu, dan sesungguhnya aku dari orangorang Islam (yang tunduk patuh kepadamu)"

Anak juga dilarang berkasar dengan ibu sebagaimana telah disebut dalam firman Allah SWT: 


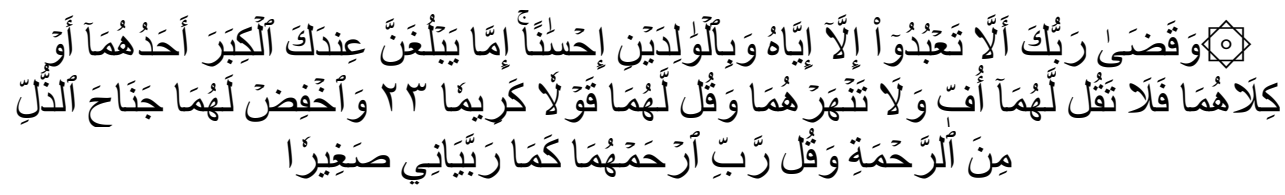

"Dan Rabbmu telah memerintahkan supaya kamu jangan beribadah kepada selain Dia dan hendaklah kamu berbuat baik pada ibu bapamu dengan sebaikbaiknya. Jika salah seorang di antara keduanya atau kedua-duanya sampai berumur lanjut dalam pemeliharaanmu, maka sekali-kali janganlah kamu mengatakan kepada keduanya perkataan "ah" dan janganlah kamu membentak mereka dan ucapkanlah kepada mereka perkataan yang mulia, Dan rendahkanlah dirimu terhadap mereka berdua dengan penuh kesayangan dan ucapkanlah: "Wahai Rabbku, kasihilah mereka keduanya, sebagaimana mereka berdua telah mendidik aku waktu kecil." (Surah Al-Isra': 17)

Disebutkan lagi bahawa berbakti kepada ibu adalah jihad sebagaimana dalam Hadith riwayat Al-Bukhariy:

“Saya bertanya kepada Rasulullah SAW, 'Amalan apa yang paling dicintai Allah?' Rasulullah SAW menjawab, 'Solat pada waktunya,' Kemudian aku bertanya lagi,'Kemudian apa lagi?' Rasulullah SAW menjawab, 'Berbakti kepada orang tua,' Aku bertanya lagi, 'Kemudian apa lagi?' Rasulullah SAW menjawab, 'Jihad fi sabilillah'”. (Al-Bukhariy, 2002)

\section{Kesimpulan}

Secara kesimpulannya, objektif kajian ini adalah untuk mengenal pasti bentuk dan tujuan amr bagi konteks iddah dan penyusuan dalam surah al-Baqarah serta rahsia tersirat penggunaan uslub amr terhadap wanita dalam surah al-Baqarah. Berdasarkan dapatan tersebut didapati semua bentuk yang digunakan adalah uslub khabariy yang memberi makna insyaiy iaitu dua ayat bagi konteks iddah dan satu ayat bagi konteks penyusuan. Tujuan amr bagi konteks yang digunakan adalah bersifat hakiki atau secara langsung iaitu wajib dan sunat. Hal ini kerana ia melibatkan hukum hakam terhadap wanita lebih-lebih lagi membincangkan mengenai iddah dan penyusuan. Hasil dapatan kajian mendapati bahawa uslub khabariy yang memberi makna insyaiy berdasarkan pendapat Wahbah Al-Zuhayliy menyatakan bentuk tersebut bersifat kelembutan. Penggunaan gaya bahasa amr memainkan peranan penting dalam menyampaikan mesej yang lebih berkesan sama ada mesej tersurat atau tersirat. Justeru, kajian ini menunjukkan bahawa Allah SWT memuliakan wanita dengan menggunakan penggunaan uslub amr yang khusus untuk mereka yang bersifat kelembutan. Sesuai dengan pendapat Ma'luf yang menyatakan bahawa al-untha memberi maksud lembut dan tidak keras. Implikasi kajian telah merumuskan bahawa uslub amr merupakan antara komponen penting untuk memastikan mesej atau makna tersirat ayat al-Quran 
al-Karim dapat di sampaikan dengan lebih jelas dan berkesan. Pada asalnya, amr merupakan perintah yang wajib dilaksanakan. la diguna sebagai dalil dalam menjelaskan hukum-hukum Islam tidak kira dalam apa-apa bidang contohnya solat, puasa, zakat dan sebagainya. Oleh itu, ia menjadi amat penting untuk memahami makna $a m r$ sendiri dan mengaplikasikannya dalam kehidupan yang akan menyumbang kepada kecemerlangan manusia sejagat. Secara keseluruhannya, perkara yang telah dikaji dalam kajian ini adalah berkaitan penggunaan $a m r$ dalam surah al-Baqarah. Kajian ini menumpukan kepada aspek Balaghah iaitu al-insya' al-talabiy yang berkaitan amr khususnya dari sudut bentuk-bentuk amr dan tujuan penggunaan amr serta rahsia tersirat uslub amr. Penulis memfokuskan kepada surah al-Baqarah kerana mengandungi banyak ayat amr yang mana sebahagian besar tajuk-tajuk dan hukum hakam perundangan Islam terkandung dalamnya dan selari dengan kajian ini yang hanya membincangkan berkaitan unsur amr sahaja. Penulis mencadangkan agar kajian lanjutan dapat diperbanyakkan dan dikembangkan lagi khususnya dalam bidang berkaitan balaghah. Kajian mengenai amr juga boleh diteruskan lagi dalam keseluruhan al-Quran selain surah al-Baqarah supaya ia dapat dikembangkan lagi dengan lebih terperinci. Kajian lain selain amr seperti nahy, qasr, dan lain-lain boleh dijalankan lagi supaya keindahan bahasa Arab dan keunikan gaya bahasa al-Quran dapat didedahkan kepada orang ramai sekaligus akan dapat menarik minat mereka mempelajari al-Quran. Justeru, penulis berharap agar kajian ilmiah ini dapat memberi manfaat kepada semua pihak terutama para pencinta bahasa Arab serta ilmuwan bahasa di samping dapat mendedahkan rahsia keunikan dan keindahan al-Quran itu sendiri.

\section{Rujukan}

\section{Al-Quran Al-Karim}

'Abbas.F. H. (1997). Ilm Ma'ani . Dar al-Furqan.

Abdul Wahid Salleh. (2006). Ilmu Al-Ma'ani. Bait Al-Hikmah.

Abdullah, H. (2017). Uslub hakim dalam Hadis Nabi Saw satu pendekatan dakwah berkesan. HADIS, 7(13), 1-11.

http://hadis.kuis.edu.my/index.php/inhad/article/view/33

Al-Bukhariy, M. I. (2002). Sahih Al-Bukhariy. Dar Ibn Kathir.

Al-Durrah, M. A. T. (2008). Tafsir Al-Quran Al-Karim I'rabuhu wa Bayanuhu. Dar Ibn Kathir.

Fatin Nazmim, M., Rohana, Z., \& Wan Hakimin, W. M. N. (2018). Tadabbur surah an Nisa': Suatu penghormatan terhadap wanita. Prosiding IRSYAD, KUIS, 1026, 863866.

http://conference.kuis.edu.my/irsyad/images/eproceeding/2018/1026irsyad2018.pdf

Al-Maraghiy, A. M. (1946). Tafsir Al-Maraghiy. Maktabah Mustafa Al-Babiy Al Halabiy. 
Al-Qurtubiy, Abu 'Abdullah Muhammad bin Ahmad bin Abu Bakr. (2006). Al-Jami' li Ahkam Al-Quran. Lubnan.

Al-Raziy, F. (1981). Tafsir Al-Kabir. Dar Al-Fikr.

Al-Rifa'i, \& Rafi' Taha. (2007). Al-Amr 'inda al-Usuliyyin. Dar Al-Mahabbah.

Al-Sabuniy, M. 'A. (1980). Rawai'ul Bayan Tafsir Ayat Ahkam. Maktabah Al-Ghazali.

Azhar, M. (2008). Pendidikan balaghah Arab di Malaysia. UTM Press.

Ibn Kathir, Abu al-Fida' Isma'il bin 'Amr bin Kathir al-Qurasyiy al-Dimasyqiy. (1999). Tafs i $r$ al-Qur a $n$ al-'Az i m. Dar al-Tayyibah.

Ibn Manzur. (t.t.). Lis a n al' Arab. Dar al-Ma'arif.

Kuckartz, U. (2014). Qualitative text analysis: A guide to methods, practice \& using software. SAGE Publications Ltd. https://www.doi.org/10.4135/9781446288719

Ma'luf, L. (1957). Al-Munjid fi Al-Lughah. Dar Al-Masyriq.

Mhd Ramli, M. F., Othman, M. S., \& Hajimaming @ Toklubok, P. (2015). Keserasian lafaz gaya bahasa Jinas dalam Kitab Al-Hikam Al-'Ata'iyyah: Kajian nilai estetika. Issues in Language Studies, 4(2), 4-5. https://doi.org/10.33736/ils.1648.2015

Syafrijal, S. (2013). Tafsir Lughawi. Al-Talim Journal, 20(2), 421-430.

http://dx.doi.org/10.15548/jt.v20i2.39

Tantawiy, M. S. (1987). Tafsir Al-Wasit. Dar Nahdah Mesr.

Wahbah Al-Zuhayliy (1991). Tafsir Al-Munir. Dar Al-Fikr Al-Mu'asir.

Yahya, M., \& Fatchur, R. (1986). Dasar-dasar pembinaan hukum fiqh Islami. PT. Al Ma'arif. 